\title{
A complexidade da relação escola-família em territórios \\ vulneráveis
}

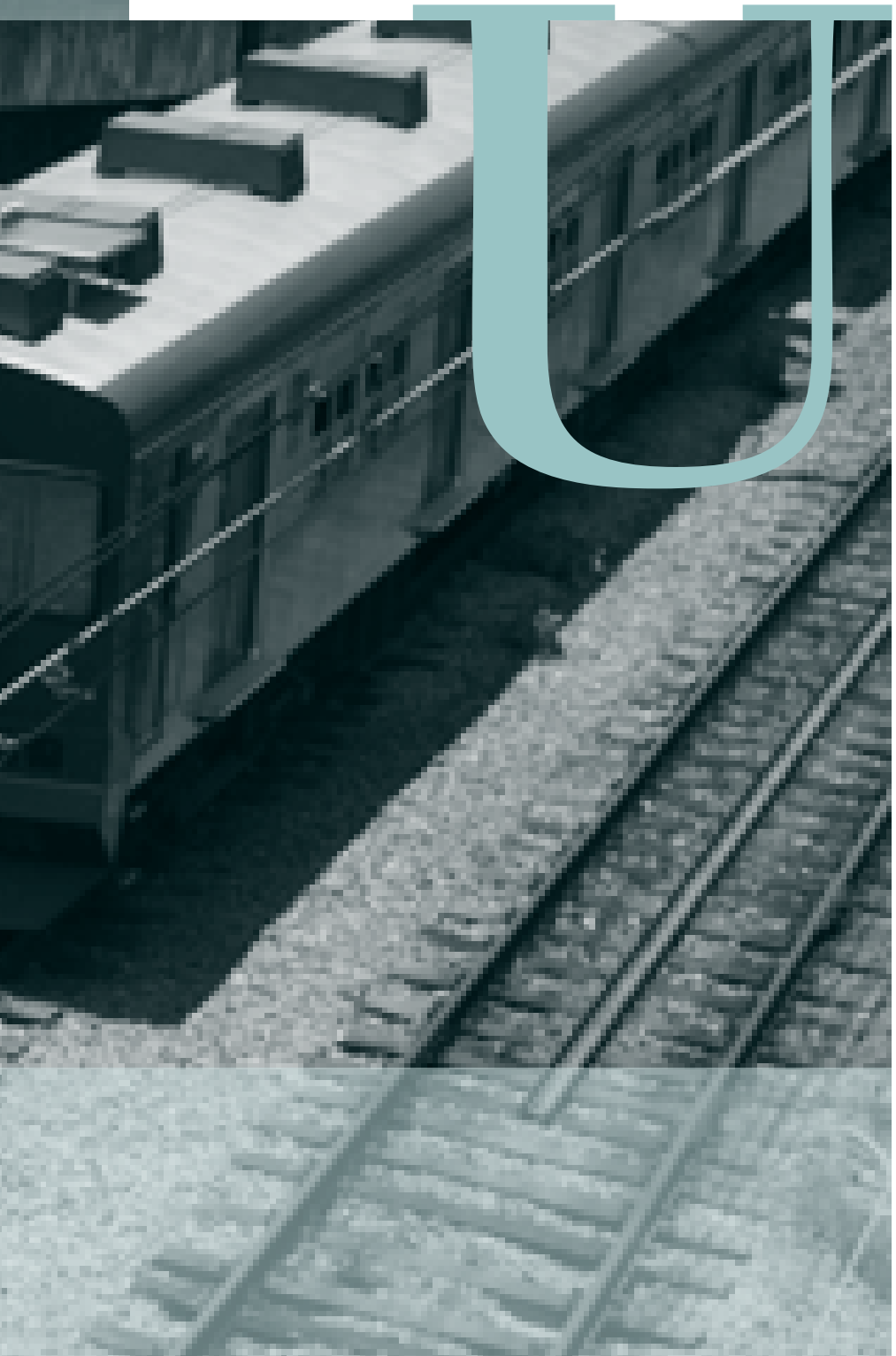

ma rodovia, dois córregos e uma linha de trem delimitam as bordas de uma comunidade da Zona Leste da cidade de São Paulo. Sem saneamento básico e rede de esgoto, o improviso das mangueiras que compõem o encanamento das casas explicita a relação paradoxal entre a criatividade e a vulnerabilidade social de seus moradores. Cada um deles traz ao espaço público os fios singulares de sua história, para tecer possibilidades de convivência familiar e comunitária na trama desagregada de um território onde não há creche, escola de educação infantil - EMEl, Unidade Básica de Saúde - UBS e cobertura do Programa de Saúde da Família - PSF.

Territórios vulneráveis como esse são encontrados em diversas regiões do país. Um universo de questionamentos se abre no contato mais estreito com moradores dessas localidades.

- Quem são essas pessoas?

- O que pensam do mundo?

- Sonham?

- O que comemoram?

- Sofrem?

- O que as mobiliza?

- Quais são suas potências e dificuldades?

* Beatriz Penteado lomonaco é psicóloga, mestre em Educação pela FE-USP, doutora em Sciences de l'Education pela Université Paris VIII e pós-doutora pela FE-USP. Trabalha na Fundação Tide Setubal. E-mail: 〈bplomonaco@uol.com.br〉.

Thais Christofe GarRafa é psicóloga e psicanalista. Trabalha no projeto Ação Família São Miguel Paulista, da Fundação Tide Setubal. E-mail: 〈tgarrafa@terra.com.br〉. 
Compreender o que a escola representa para essas mães, quais são as especificidades de aprender na escola ou em outros lugares, qual é o papel dessa instituição na comunidade em que vivem é tratar de sua relação com o saber. Isso permite identificar algumas portas através das quais essas mães e seus filhos podem se inserir no universo escolar, sem deixar sua identidade e sua história para trás.

\section{A trajetória escolar das mães e sua relação com o saber}

luzes sobre essa difícil relação, na tentativa de identificar de que fios é constituído o laço da família com a escola em territórios de alta vulnerabilidade social.

Ao amplificar e fazer reverberar as vozes das mães, procuraremos deslindar os sentidos que elas atribuem à escola, em termos de valores, de significados e de práticas, a partir da relação da família com o território - apresentada na oposição entre a escola e a rua - bem como de suas próprias experiências escolares e daquelas que têm como mães de alunos.

O conceito de relação com o saber é central nessa análise, porque recobre o seu caráter social e o subjetivo. Bernard Charlot, professor emérito em Ciências da Educação da Universidade Paris VIII e professor-visitante na Universidade Federal de Sergipe - UFS, tem trabalhado esse conceito há vários anos.

As pesquisas sobre o tema ultrapassaram as fronteiras francesas e são hoje desenvolvidas em diversos países, inclusive no Brasil. A maior parte delas tem como foco principal a relação de alunos e professores com 0 saber, mas o conceito não se limita aos atores do campo escolar.

Entende-se por relação com o saber

[...] uma relação de sentido, portanto de valor, entre um indivíduo (ou um grupo) e os processos ou produtos do saber (Charlot, Bautier e Rochex, 1992),

ou, ainda, em uma formulação mais recente:

A relação com o saber é a relação com o mundo, com o outro e consigo mesmo de um sujeito confrontado à necessidade de saber (Charlot, 2005).

A educação é tanto transmissão de um patrimônio como autocriação singular. Ela é encontro de uma história coletiva e de uma história singular, tendo cada uma dessas uma escala temporal diferente.

Charlot apud Dieb, 2008, p. 177.

À primeira vista, a análise das entrevistas permitenos observar uma série de similitudes nas trajetórias de vida dessas mães. De fato, elas existem e devem ser exploradas. De certo modo, aquilo que aparece como constante e homogêneo produz conforto ao pesquisador por possibilitar a elaboração de explicações plausíveis para suas inquietações.

Entretanto, vidas são singulares e, como tal, produzem efeitos e sentidos heterogêneos. Logo, é importante analisar o objeto de estudo de diferentes perspectivas, sem evitar as tensões que delas emanam, a fim de dar conta de processos e relações dos sujeitos com a escola. Como afirma Velho (apud Zago, 2007, p. 20):

\footnotetext{
[...] por mais que seja possível explicar sociologicamente as variáveis que se articulam e atuam sobre biografias específicas, há sempre algo irredutível, não devido necessariamente a uma essência individual, mas sim a uma combinação única de fatores psicológicos, sociais, históricos, impossível de ser repetida ipsis litteris.
}

Os personagens desse enredo são nossos conhecidos, rostos comuns em quaisquer periferias urbanas. Quase todas são migrantes: Marta, Sônia, Jucilene, Jandira, Cláudia e Fátima vêm do Nordeste (RN, BA, CE, PI) e Edileusa, da região Sul (PR). Somente Denise nasceu e cresceu na capital paulista. ${ }^{2}$ São mulheres jovens, na casa dos 30, com exceção de Marta, que tem 58 anos. Em relação ao estado civil, seis são casadas, uma separada e uma viúva. Todas elas têm vários filhos: de três até seis crianças. ${ }^{3}$ 
Em residências precárias e com espaço exíguo (em geral, sala, quarto, cozinha e banheiro), moram não menos de cinco pessoas. A renda familiar oscila entre $R \$$ 350,00 e $R \$ 880$,00 e provém do trabalho do companheiro, de uma ajuda dos filhos ou de parentes e ainda de projetos sociais aos quais os membros da família estão vinculados, já que nenhuma delas tem emprego fixo.

O histórico escolar das mães é emblemático, traduzindo as principais mazelas da educação no país, nos últimos 30 anos. Das oito mães entrevistadas, somente uma, a única nascida e criada na capital, teve um percurso escolar regular e chegou até a $8^{\underline{a}}$ série, quando interrompeu os estudos por causa da gravidez.

As demais têm histórias semelhantes: moravam na zona rural, freqüentavam escolas com classes multisseriadas, têm percursos escolares intermitentes, como ainda é o caso de muitos alunos, mesmo em regiões mais prósperas. Três delas pararam no ciclo inicial ( $1^{\underline{a}}$ e $2^{\underline{a}}$ série), outras três também interromperam os estudos no antigo curso primário, mas voltaram a estudar recentemente no EJA: Fátima está na $7^{\underline{a}}$ série, Marta acaba de terminar o ensino médio e Jandira está no primeiro segmento do EJA. Cláudia nunca foi para a escola; é capaz de ler, mas não escreve.

Os afastamentos e retornos à escola se dão em razão da sobrevivência: mesmo em tenra idade, elas assumiam as tarefas domésticas, o trabalho na roça e o estudo, o que, naturalmente, leva qualquer criança a uma grande fadiga. Quase todas se referem a situações de intensa pobreza, em que a alimentação era tão escassa que algumas delas trabalhavam em troca de comida.

Poucos pais se incomodaram com esses afastamentos da escola, era preciso contar com mais braços e força de trabalho - como diz Fátima:

[...] na minha época, barriga era mais importante.

Algumas delas demoram vários anos para fazer uma nova tentativa de estudar e, mesmo mais velhas, essas retomadas também não são lineares e podem ser interrompidas por diversas razões. Exceção de Marta, que retoma os estudos na quarta série do EJA e prossegue sem interrupções até o momento da entrevista, quando está no final do ensino médio.

\section{Os afastamentos e retornos à escola se dão em razão}

\section{da sobrevivência: mesmo}

\section{em tenra idade, as crianças \\ assumiam as tarefas \\ domésticas, o trabalho}

na roca e o estudo, o

que, naturalmente, leva

qualquer crianca a uma

grande fadiga.

\section{Injustiça e angústia}

\section{Quando crianças, a relação com a escola revela certa}

tensão em todos os casos. As repetências são comuns, por faltas ou dificuldades no estudo. A palmatória era costume, assim como castigos vexatórios que lembram relatos do século XIX ou do início do século XX, muito embora a escolarização dessas mulheres tenha ocorrido na década de 1970, quando essas práticas não eram mais aceitas.

Fátima, uma das entrevistadas mais atuante e curiosa, interrompe definitivamente os estudos por volta dos 12 anos quando uma professora não acredita que seu bom resultado nas provas tenha sido mérito próprio, e sim fruto de "cola", erro considerado "gravíssimo". Mesmo faltando muito, Fátima diz que conseguia acompanhar as aulas, mas a professora não lhe deu crédito. A indignação tomou conta dela:

Eu entendia lá e respondi direitinho, e aí eu fiquei decepcionada assim, fiquei triste e daí já saí para trabalhar fora, eu acho que mais por isso, para mim acabou.

Os sucessivos fracassos predominam em todas as histórias. Denise nunca passou da primeira série e revela seu grande embate com a resolução de problemas na matemática:

[...] tinha problema de desmaio e era um problema. Quando chegava no problema, era problema mesmo [...] acho que não entrava na cabeça. Você ler, pôr o resultado, que os problemas você tem que ler para pôr o resultado e eu não conseguia ler, então não saía nada. 


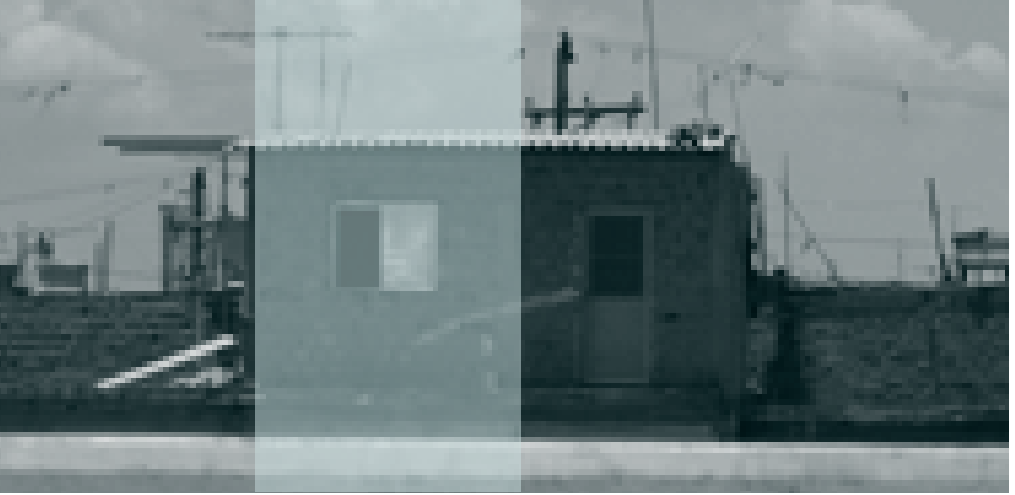

Pode-se imaginar quão angustiante era ficar às voltas com uma tarefa enigmática e interminável, uma vez que sua saída era condicionada ao término da atividade.

Cláudia e Marta não freqüentaram a escola quando crianças; aprenderam as primeiras letras com a mãe e com a madrinha de criação, respectivamente. No caso de Marta, há um interesse em aprender mais intenso que o de Cláudia. A infância de Marta no campo foi marcante:

Eu não fui criada por pai e mãe, fui criada por outras mãos, então eu fui muito sofrida e eu queria aprender porque queria. Então eu estudava à noite. [...] A minha madrinha me ensinava, nessa época não tinha energia, eu estudava com lamparina, queimava meus cabelos. [...] Eu fui até o terceiro ano com ela. Em casa mesmo, eu não ia para o colégio, eu não podia ir porque, naquele tempo, eu trabalhava muito, a luta lá em casa era muito grande, era casa de vaqueiro, nesse tempo não era fazendeiro, lá eu lavava roupa, eu quebrava coco, eu fazia tanta coisa.

De alguma forma, essa disposição para o estudo permaneceu latente, permitindo a Marta entrar na escola em idade adulta.

Nesse caso, assim como ocorreu com Fátima, Jandira, Edileusa e Sônia, a despeito dos percursos entrecortados, a relação que tiveram com a escola na infância não impediu que tentassem retomar os estudos em algum momento da vida. As três que estão estudando atualmente falam sobre isso com muita animação, revelando a importância desse investimento pessoal.

Em outras situações, contudo, um percurso escolar acidentado pode ter sido um ingrediente para que uma retomada se inviabilizasse, mesmo quando condições concretas parecem mais favoráveis (proximidade da escola, filhos maiores, tempo livre em virtude do desemprego etc.), como é o caso de Denise, Sônia, Cláudia e mesmo o de Edileusa, que voltou a estudar este ano, mas sucumbiu aos pedidos do marido para que parasse.

Denise e Cláudia, que têm pouco estudo, apresentam um discurso ambíguo em relação à escola. Cláudia diz:
A pessoa ser pobre, ser bem-educada, ter um estudozinho, está bom demais, né?

Entretanto, Sônia, que também estudou pouco, tem um nível de participação social notável (APM, Conselho Escolar, igreja, ONG) e revela uma relação com a escola dos filhos bastante diversa das duas primeiras. Isso mostra que a baixa escolaridade das mães não é fator determinante para um "desinvestimento" nos estudos formais.

Mas é nas entrevistas de Jandira, Fátima e Marta, que retomaram os estudos, que se observa um entusiasmo maior com as possibilidades da escola: lêem muito, incentivam os filhos, participam. Além disso, são elas que ressaltam com mais força argumentativa que o estudo seria uma possibilidade eficaz de ascensão social.

Quando Marta fala dos sonhos que tem para seus filhos, o ensino superior desponta como uma possibilidade gloriosa:

Universidade para ser alguém, sinceramente... Deus que me perdoe, eu tenho uma inveja tão grande quando eu chego em um banco para fazer qualquer coisa, uma lotérica [...] que eu vejo aquelas pessoas vestindo assim uniforme, que está trabalhando ali, sabendo tudo ali, eu fico olhando e pensando: será que eu vou ter sorte de ver alguém meu fazendo isso? [...] 0 que eu digo é que eles têm que abrir os olhos para a vida, estudar bem e entender as coisas, porque se eles não fizerem isso não dá. [...] Se sair do estudo, se sair, filha, não tem roça, no interior vai pra roça, mas aqui o que tem é rua e a malandragem, só isso.

Assim, parece que, quando elas próprias conseguem ultrapassar as dificuldades e frustrações oriundas desse percurso escolar acidentado, quando percebem os ganhos efetivos do estudo, seja em termos de desenvolvimento pessoal, seja de perspectiva profissional, o valor da educação formal aumenta e deixa de ser apenas uma retórica.

Jucilene, a única que chegou à oitava série sem interrupções, também apresenta um discurso mais consistente em relação à escola e se atém, inclusive, ao seu caráter formativo:

[...] mas aí, conforme o tempo, eu fui lendo livros, entendendo o que era o mundo aqui fora, entendeu? Fiz bastante burrada na minha vida, superei todas elas. Um pouco do meu estudo que eu tive, hoje eu sei o suficiente. Sei meus direitos, os direitos dos outros, entendeu? Então Deus entrou sem sair. 


\section{Concorrência vida e escola}

\section{Se uma relação difícil ou entrecortada com a escola não}

impede um retorno a ela, estar na escola ou ter estado por um período mais longo permite que melhor compreendam sua lógica. Entendemos por lógica o modo de operar da escola, suas regras, burocracias, relações e, sobretudo, as especificidades da apropriação dos conhecimentos escolares.

Além disso, essas mães parecem transmitir algo mais do que possibilidade de progredir por meio da escolaridade, elas transmitem certo encantamento pelo que aprenderam e pelos horizontes abertos pelo conhecimento, elas comunicam aos filhos o desejo de saber, imprescindivel a toda aprendizagem. Segundo Charlot (apud Dieb, 2008, p. 178):

Na escola, só aprende quem desenvolve uma atividade intelectual. Não se pode aprender no lugar de ninguém, já que a educação implica um movimento de “dentro”. Não há mobilização intelectual sem desejo e este esmorece se nunca leva ao prazer da satisfação. Sempre uma atividade visa a um objetivo, um resultado, mas o que a sustenta, o que the dá sentido e confere sentido ao objetivo é o desejo e o prazer antecipado da satisfação deste.

As narrativas parecem então mostrar que o sentido da escola é adensado pelas experiências escolares das mães.

Outro ponto que chama a atenção nas entrevistas é a diferença essencial entre o modo como os pais das entrevistadas lidavam com a escola e a maneira como elas, como mães, o fazem. Na geração anterior, são raros os pais que fizeram restrições ao abandono escolar de suas filhas, sobretudo porque o contexto social e as condições de vida eram bastante diferentes.

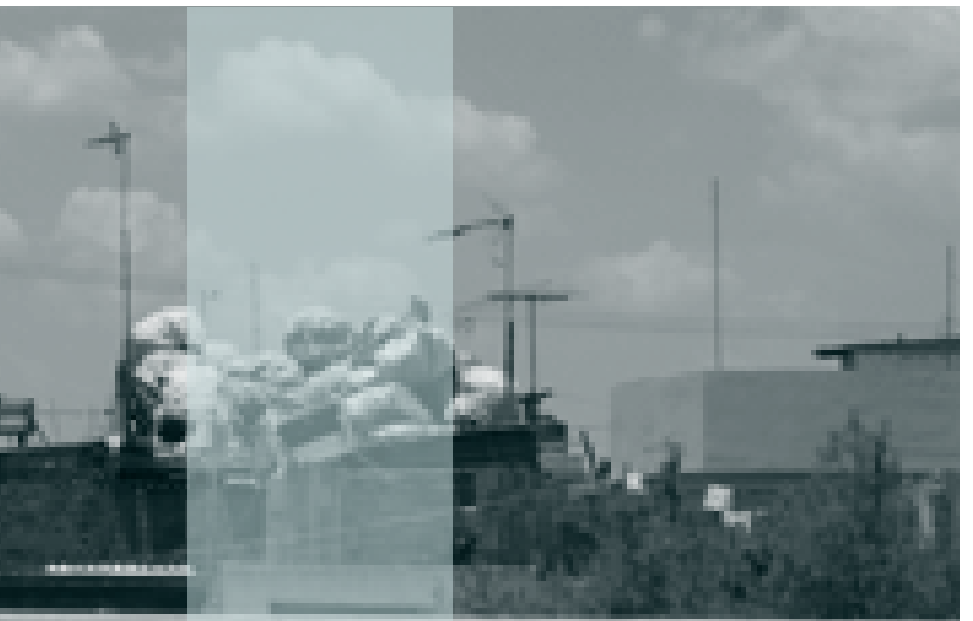

Quando a escola e a vida concorrem, como era o caso da vida na roça, é preciso escolher entre elas, processo ao qual Charlot (2001, p. 150) identifica como ruptura sem continuidade. Já, como mães, as entrevistadas vêem o fracasso escolar de seus filhos (seja na forma de abandono, de desinteresse ou de repetência) com grande preocupação.

Para elas, a escola é mais do que uma possibilidade de aprender, é a única saída para se "ter uma vida meIhor". 0 estudo, para todas elas, confere um lugar social, dá um nome e uma identidade. Essa identidade traz a história do sujeito (e de seus antepassados) e o lança para o futuro, como uma nova possibilidade de ser um igual (aos seus), mas também um novo.

Essa diferença no modo de encarar a escola provoca também outro envolvimento com as transformações que toda aprendizagem implica - no próprio sujeito, que passa a saber algo que desconhecia, e no meio, porque esse saber opera mudanças objetivas e subjetivas.

As mães se confrontam, portanto, com um trabalho de reedição e transformação de suas próprias histórias. Assim, a escolaridade dos filhos tem uma representação singular para cada uma delas. Seria possibilidade de revanche, de superação ou de repetição da sua própria escolaridade? Colocando de outra forma, o que significa os filhos as ultrapassarem?

Estudando o sucesso e o fracasso escolar de jovens franceses, Jean-Yves Rochex afirma que:

\footnotetext{
[...] assim, entre gerações, entre pais e filhos, está em jogo um fenômeno de tripla autorização que parece condição da apropriação das mobilizações e dos projetos parentais: se os jovens se autorizam, sem grandes dificuldades subjetivas, a serem outros que seus pais, sem reproduzir sua história, não é apenas porque são simbolicamente autorizados por estes, mas que, por sua vez, reconhecem a legitimidade dessa história e dessas práticas que não querem reproduzir. É o reconhecimento de cada um - filhos e pais - de que a história do outro é legítima sem ser a sua, que torna possível esse processo de tripla autorização e que permite à história familiar, por meio das crianças, de prosseguir sem se repetir, e isso sem atuações nem conflitos graves ou insuperáveis. (Rochex, 1995, p. 260).
}

Nas entrevistas, observa-se que algumas, de fato, esperam que seus filhos as superem, e a escola então representa a possibilidade de ultrapassagem. 
A escola, tal como se

encontra em muitos locais

da periferia, é o símbolo

vivo da degradação da

educação e do descaso

com a população, o que

confirma, escancara e

facilita a reprodução da

precariedade em suas vidas.

Nunca passei para os meus filhos que eu tive problema na escola, porque eu quero que eles estudem,

afirma Denise, para quem ocultar o passado é condição para manterviva a aposta na possibilidade de superação dos fracassos que marcaram sua trajetória.

Ainda na direção da superação, a fala de Jucilene explicita uma outra forma de processar essa transmissão transgeracional:

[...] a única que não estudou da minha família foi a minha mãe, que era analfabeta, né? Mesmo assim, ninguém passava a perna nela na conta, né? De vez em quando, eu tentava lá rapar um pouquinho do dinheiro dela, mas lidar com a conta ela sabia, né? E ela veio aprender a escrever comigo. Eu ensinei a ela, né? Escrever o nome dela. Ela veio a aprender com 40 anos a escrever o nome dela.

Por tervivido essa diferença geracional de modo positivo, Jucilene parece lançar a mesma possibilidade para seus filhos: que sejam diferentes dela sem que isso implique desvalorização da família e traição das expectativas maternas.

Evocê sabe que a mãe sempre deseja que o filho realize um sonho, né? E se ele conseguir realizar o sonho dele, melhor pra ele, bom pra mim também, né?

Outras mulheres, porém, não vislumbram mais do que uma sobrevivência digna, ou seja, que os filhos tenham um trabalho que lhes permita ter um teto e constituir família. Diz Cláudia:

Eu sonho de dar um futuro melhor para os meus filhos, né? [...] cada um ter seu lugarzinho para morar...
Nesses casos, a escola parece ser uma possibilidade de se manter como se é, de modo que a representação de "um futuro melhor" reside na possibilidade de os fiIhos conquistarem com menos esforço aquilo que as mães conquistaram a duras penas.

Os sonhos podem surgir sorrateiramente, explicitamente ou com titubeios, mas eles aparecem, revelando uma aposta em uma vida melhor, mais tranqüila, o que, na maior parte dos casos, é recheada do simples, até do mínimo de dignidade da condição humana.

E o sentido da escola também está lá, tramado com as linhas do passado e do futuro e ainda com as de fora (da rua, da vida) e as de dentro (da escola, da família). E essa trama que tece fios múltiplos e articulados se atualiza no cotidiano escolar que robustece (ou enfraquece) o tecido de sentidos construído por alunos e pais.

Lições, regras, reuniões - a escola vista pelas mães.

Tanto as entrevistadas quanto os outros pais que participam de reuniões socioeducativas do projeto Ação Família expressam desejos, condições e expectativas em relação à escola dos filhos. Muitas vezes, não somente pais, como também adolescentes apontam um paradoxo de difícil resolução: a escola não é boa (nesse sentido, denunciam a falência do sistema público de ensino), mas ela salva (o que revela também uma supervalorização dos estudos formais).

E por que a escola não é boa? Professores faltam, não têm respeito pelas crianças (há relatos de violência física e psicológica), são autoritários, a comida é ruim, falta segurança e todo tipo de material (em uma delas pedese para levar papel higiênico).

A escola, tal como se encontra em muitos locais da periferia, é o símbolo vivo da degradação da educação e do descaso com a população, o que confirma, escancara e facilita a reprodução da precariedade em suas vidas.

Apesar disso, uma boa escola é, ao contrário, limpa, organizada, os profissionais são atenciosos e as crianças aprendem. Algumas mães citam a necessidade de biblioteca. Também são mencionados como pontos positivos, a oferta de calçado e de uniforme, as provas (que permitem que o aluno estude) e os espaços alternativos para o lazer, como salas de leitura e de vídeo, campo de futebol, passeios, festa junina e atividades aos sábados.

É importante ressaltar que a percepção das mães sobre as escolas da região coincide com os resultados 
observados no Índice de Desenvolvimento da Educação Básica - Ideb, 4 ou seja, as escolas mais valorizadas são de fato as que apresentam melhores resultados neste índice.

E o que essas mães valorizam nas condutas e práticas escolares? Alguns pontos são reincidentes, nas conversas, como práticas e atitudes consideradas imprescindíveis para uma aprendizagem adequada.

Esperam, por exemplo, que as professoras sejam atenciosas, respeitosas e, sobretudo, rígidas. Sabem, pelo que vêem e pelo relato de seus filhos, que muitas escolas vivem um caos: crianças se batem, ofendem-se, roubam, agridem professores, não cumprem as responsabilidades, desrespeitam e são desrespeitados.

Há diversas queixas de agressão física e verbal dos adultos, de castigos (como colocar na criança um chapeuzinho escrito "boboca") e de atitudes preconceituosas dos professores (com crianças com necessidades especiais, com negros, com os que têm menos e "usam sempre as mesmas roupas", entre outros).

As mães têm consciência de que as crianças são difíceis e é preciso ser firme, o que não implica agressões, humilhações e castigos. Pode-se enxergar aqui um pedido de limite, de enquadramento, porque compreendem que algumas condições são necessárias para aprender - ordem, harmonia e respeito, por exemplo. Mas podese ainda compreender nesse discurso que diretores ou professores rígidos encarnam a ordem, não apenas aquela disciplinar, como também a ordem simbólica que restaura a lei, o poder da escola como instituição do saber, que guarda e legitima a cultura, os saberes dos antepassados e permite transformar trajetórias no futuro.

Entre as práticas reiteradamente mencionadas, as lições de casa e as reuniões aparecem com freqüência. A lição é importante, primeiro porque ocupa as crianças e também porque dá lugar a certa solidariedade familiar valorizada: uns ensinam os outros.

Todas as mães acham que devem acompanhar as lições de casa e criam estratégias para fazê-lo, mesmo as analfabetas, como conferir a data no caderno ou ver o quanto ele está preenchido.

As lições parecem ser entendidas como um atestado de competência do professor, talvez porque permita a elas, dentro de casa, ver que a escola se mostra consonante com as suas principais expectativas: empenho em ensinar e dar oportunidade para que a criança faça outra coisa que não ficar na rua.

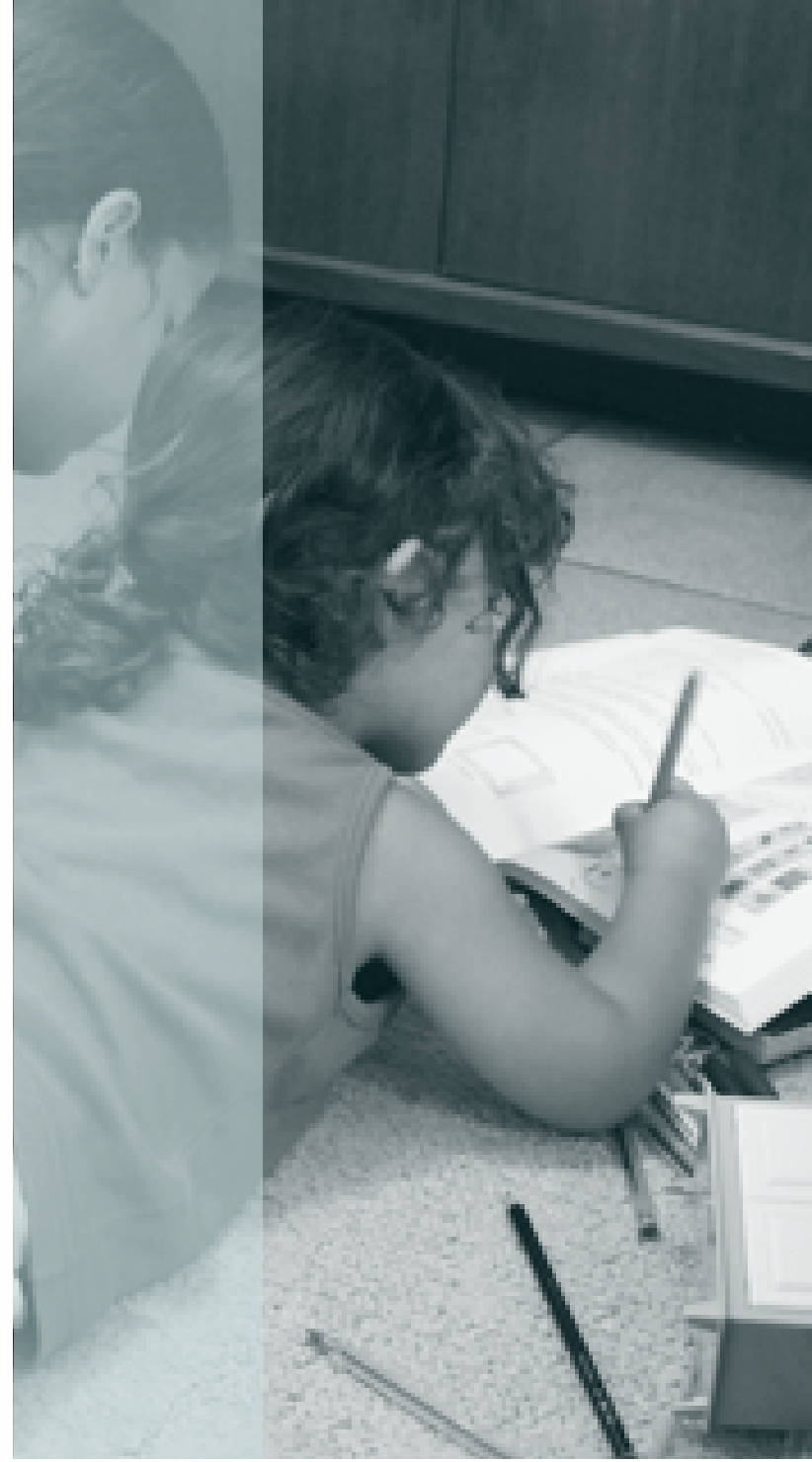

Quanto às reuniões, as mães esperam que ocorram e que os professores falem de seus filhos, mas ressaltam a necessidade da intimidade: não é para falar dos filhos em público. Todavia, não é apenas o desenvolvimento da criança que as interessa:

Deveriam fazer reuniões para saber o que os pais acham da escola. Jucilene

Se houvesse mais reunião, mudaria alguma coisa.

Fátima

Os pais deveriam organizar reuniões sem os professores para tentar melhorar a escola.

Sônia

Algumas acham que as reuniões são repetitivas, falase sempre a mesma coisa. Várias culpam outros pais por não participarem ou não se interessarem pela escola e muitas delas confessam que também não comparecem todas as vezes. 
As mães com maior

\section{experiência escolar}

parecem, no entanto,

mais aptas a intervir na

aprendizagem de seus filhos

e eventualmente até a se

engajar na promoção da melhoria da escola.

Em muitas entrevistas, observa-se uma valorização do esforço da própria criança: é ela que precisa prestar atenção, escutar o professor, fazer a lição, esforçar-se. 0 voluntarismo atribuído à criança parece mostrar que 0 principal está nas mãos dela e não expressa com clareza o papel decisivo do professor na aprendizagem.

Daí a grande frustração que sobrevêm quando a criança passa por dificuldades: o próprio filho parece não ter condições de aprender, tal como ocorreu (ao menos em parte) com seus pais. A repetição de uma trajetória fracassada se anuncia e atualiza o sofrimento que a acompanha.

Afora o aprendizado da leitura e da escrita, mais evidente em termos de resultado, as mães não sabem precisar exatamente o que seus filhos aprendem, mas isso não impede que saibam avaliar alguns aspectos do trabalho do professor.

Os exemplos são inúmeros e variados.

As professora fala muito, né? Só. E deixa muito as crianças brincar à vontade. Não deveria ser assim, né?

Cláudia

O Luiz melhorou quando colocou umas menina pra ajudar na sala. Eu acho que as outras escola também precisaria ter esse tipo de apoio, sabe? Com uma professora só, eu não sou contra elas, só acho que elas deve treinar muito, entendeu?

Sônia

Além de ensinar, as mães pedem que os professores respeitem seus filhos, como diz Jucilene:

O importante é eles estar aprendendo, dar o respeito e ser respeitado.

0 que podemos perceber nessas pinceladas sobre 0 funcionamento da escola corrobora algumas reflexões anteriormente formuladas. Independente do grau de escolarização, as mães sabem o que esperar do ensino dado aos filhos: utilizam os recursos disponíveis para avaliar o que observam e dão muita importância aos professores, procedimentos, práticas, comportamentos, conhecimentos e valores transmitidos pela escola.

As mães com maior experiência escolar parecem, no entanto, mais aptas a intervir na aprendizagem de seus filhos e eventualmente até a se engajar na promoção da melhoria da escola, mas essas experiências não são condições necessárias para um bom desempenho escolar das crianças.

Observamos ainda que o cotidiano escolar tem o potencial de transformar a trama de sentidos que a família atribui a escola e, paralelamente, pode fazer com que 0 sentido da escola se fortaleça (ou se enfraqueça) à medida que essas práticas ampliam significados para pais e alunos.

A seguir, ultrapassando o universo das trajetórias e práticas escolares, avançaremos na discussão sobre o sentido que as famílias atribuem à escola, com base na análise de alguns aspectos do território onde vivem.

\section{Nosso samba ainda é na rua}

Nos territórios mais vulneráveis, a frequente associação da escola com um lugar que permite que as crianças não fiquem nas ruas é compreendida, pela maioria dos educadores, como uma desvalorização do ato de educar, porque minimizaria a importância do que consideram a função primordial da escola, qual seja, a transmissão de conhecimentos.

Essa percepção impede, porém, a reflexão sobre a relação da escola com o território e a construção de uma posição crítica e singular da instituição a respeito de sua permeabilidade e abertura para a comunidade e para as demandas apresentadas no discurso familiar.

Veremos adiante como a análise dessa relação redimensiona a importância da alusão que as famílias mais vulneráveis fazem à escola, na demarcação de um espaço de resistência à violência urbana e na sustentação das potencialidades dos pais na educação de seus filhos.

0 desamparo infantil diante do risco de acidentes na rua e da violência praticada pelos mais velhos faz parte das preocupações maternas. Jandira esclarece:

A gente fica muito preocupado, porque as crianças na rua, essas coisas, é perigoso também, passa uns caras de moto aí, passa na maior velocidade, a gente fica preocupado. 
É no discurso de Jucilene, porém, que o contraste entre a delicadeza das defesas da criança e a violência no território adquire intensidade e nos aproxima dos temores dessas mulheres:

\footnotetext{
A violência aí fora... é tanto que eu não sabia, estupraram uma menina de três anos aqui atrás [...] Então, o meu maior medo é esse daí [...] É tanto que os próprios cara abafou o caso, né? Pra comunidade não ficar sabendo. Eles falou que isso prejudica nós que somos mãe.
}

A impossibilidade de metabolizar esse excesso violento que atravessa as ruas é reconhecida pela sabedoria comunitária. A vizinhança que "abafa o caso" para preservar as mães revela sua inquietude diante da dificuldade de educar quando a vida familiar é inundada pela preocupação com problemas alarmantes, que estão fora de seu campo de intervenção.

No entanto, apesar dos esforços na construção de filtros e anteparos, os sons da violência na rua se fazem ouvir e deixam restos aos quais se ligam os maiores pesadelos dessas mulheres:

\footnotetext{
Ah, a gente sonha, né? Tantos sonhos vêm ruim que depois a gente fica com medo [...] Sempre tem um matando o meu filho, eu tava vendo tanta barra que o homem saía atirando nele e eu não, não, né? Eu não sei se é porque outro dia teve uns tiros aqui na rua, eu comecei a gritar, sonhei umas três vezes a mesma coisa.
}

Cláudia

A ameaça de perder o filho penetra a vida familiar e 0 universo onírico de Cláudia, refletindo a intensidade com que o maior índice de vulnerabilidade juvenil da cidade se apresenta no cotidiano dos moradores do bairro. ${ }^{5}$

De modo semelhante, o homicídio, segunda maior causa de mortes na região, ${ }^{6}$ produz impactos no cotidiano da família de Jucilene, que perdeu seu filho mais velho em situação de conflito no tráfico:

Porque quem já perdeu um filho, tem medo de perder outro. Então, o meu maior medo é esse [...] Entendeu? Então, igual eu, eu moro aqui, dez anos e pouco, né? Por isso eu já conheço a região como é que é. Então, o meu maior medo é esse daí, as drogas, violência.

A estreita relação entre drogas e violência é recorrente e porta um campo de possibilidades e convocatórias em relação ao qual cada criança ou jovem terá de se posicionar. Os relatos das mães explicitam a dificuldade da família em resistir ao que então se apresenta como uma "tentação" que vem da rua, um "saber indesejado".

Fora da escola não aprende é nada, sabe por quê? Aprende é o que não presta. É o que tem aí oferecendo aí toda hora nas portas.

Marta

Na família de Edileusa, é seu filho mais velho, Douglas - jovem de 16 anos que deixou a escola aos 13 e participa do tráfico - quem faz uma firme oposição à presença da irmã mais nova na rua:

[...] o irmão dela não quer ela na rua, se ele pegar ela na rua, ele briga com ela, dá bronca nela.

Douglas conhece de modo particular a potência do complexo drogas-violência-tráfico e seus apelos nas relações comunitárias: oportunidades financeiras e uma posição no grupo delimitada de forma rígida e clara por meio de normas e signos próprios.?

Nesse contexto, a escola é convocada para, na aliança com a família, constituir um corpo capaz de fazer frente à intensidade com que os componentes da violência no território se apresentam às crianças e jovens:

[...] que lá dentro eles estão aprendendo a estudar, a ler e aqui fora não, aqui fora a situação é mais difícil para orientar porque a vida aqui fora é mais difícil do que eles estarem dentro da escola.

Denise

O laço com a escola como resistência às facetas da violência no território amplia a questão para além da delimitação física do espaço institucional. Não se trata de criar barreiras concretas - muros - ao território, e sim de possibilitar a construção de um lugar para o sujeito dentro de outra lógica, da qual faz parte aprender a estudar, a ler e a transitar pelas leis que organizam a vida social.

Além de oferecer um lugar para o sujeito nessa lógica, a importância do laço da família com a escola ancora-se na possibilidade de sustentar as potencialidades dos pais na educação de seus filhos. Essa sustentação opera à medida que os pais persistem na tarefa de ensinar a criança a discriminar as situações de risco do cotidiano e de transmitir valores que lhes são caros. 
A aliança com a escola nessa tarefa revela-se, assim, fundamental para que os pais não retrocedam, para que não desistam diante dos apelos que atravessam insistentemente essa transmissão delicada.

É Fátima quem esclarece como isso se processa em relação a seu filho:

Para ele, na verdade, assim, eu acho que ele tem uma consciência que na escola... assim quando a professora fala "olhe, isso é errado" e ele vê na rua fazendo, ele sabe que é errado fazer. Quando tem essa consciência, assim, que aprende alguma coisa na escola, que a tia explica para ele ou fala, faz algum comentário, alguém fala, aí tem que explicar para ele o porquê daquilo e ele chegar para mim e perguntar: "Mãe, o que você acha assim? Eu ouvi fulano fazer isso ou falar isso". Ele vem saber, eu acho interessante a gente explicar e ele pensar para saber se é bom ou ruim, mas ele vai saber.

As potencialidades da vida comunitária também estão presentes nas falas das entrevistadas. Se o ruído das ruas ecoa nos pesadelos maternos, suas melodias também abrem possibilidades de sonho:

\begin{abstract}
É. O sonho do João é ser bombeiro [...] na rua em que a gente morava aqui o caminhão de bombeiro passava, ele ficava assim, os cara passava, tinha um que tinha... era de lei, ele passava, puxava, né? Ele já fazia isso a propósito, o cara já acenava pra ele. [...] 0 do Tales é ser jogador [...] Jogava com os amigos na rua porque a atividade deles era mais na rua, né?
\end{abstract}

Jucilene

Os sonhos de João e Tales, filhos de Jucilene, explicitam a importância da rua como lugar dos encontros que marcam a singularidade da criança. Espaço plural, a rua oferece campos de relação em que a criança se constitui - seja através de um jogo estruturado seja do chamado ao olhar do "outro", ao qual o sujeito se enlaça a partir de um aceno-resposta.

Talvez por isso, Jucilene, apesar de seus temores, dê espaço à vontade de seus filhos:

[...] eles vêm pra casa: “Mãe, já cheguei”. E rua, entendeu? [...] É o que eles quer, né?

O que Jandira fala reforça a vitalidade desses encontros e brincadeiras:

Os filhos das vizinhas, né? Eles chamam as crianças para brincar, tem bastante criança aqui na rua. (...) Eles vão brincar, jogar videogame, brincar aí na rua, né?

Há que se considerar, enfim, a multiplicidade de elementos envolvidos na relação da família com o espaço comunitário para iluminar a importância dessa relação no laço da família com a escola.

Como vimos, para as mães, "a rua" carrega uma série de significados paradoxais. É símbolo da exterioridade, não apenas da escola, como também da família; é a "vida lá fora", onde se pode aprender, participar e se integrar à comunidade. É ainda um grande quintal para as crianças que vivem em espaços exíguos; ponto de encontro para brincadeiras; uma das poucas possibilidades de interação social.

Mas a rua também corporifica o mal, as vilezas humanas, a sedução perigosa de um mundo do qual é preciso aprender a se afastar. Em todos esses casos, porém, a rua é um lugar de investimentos afetivos importantes na vida familiar.

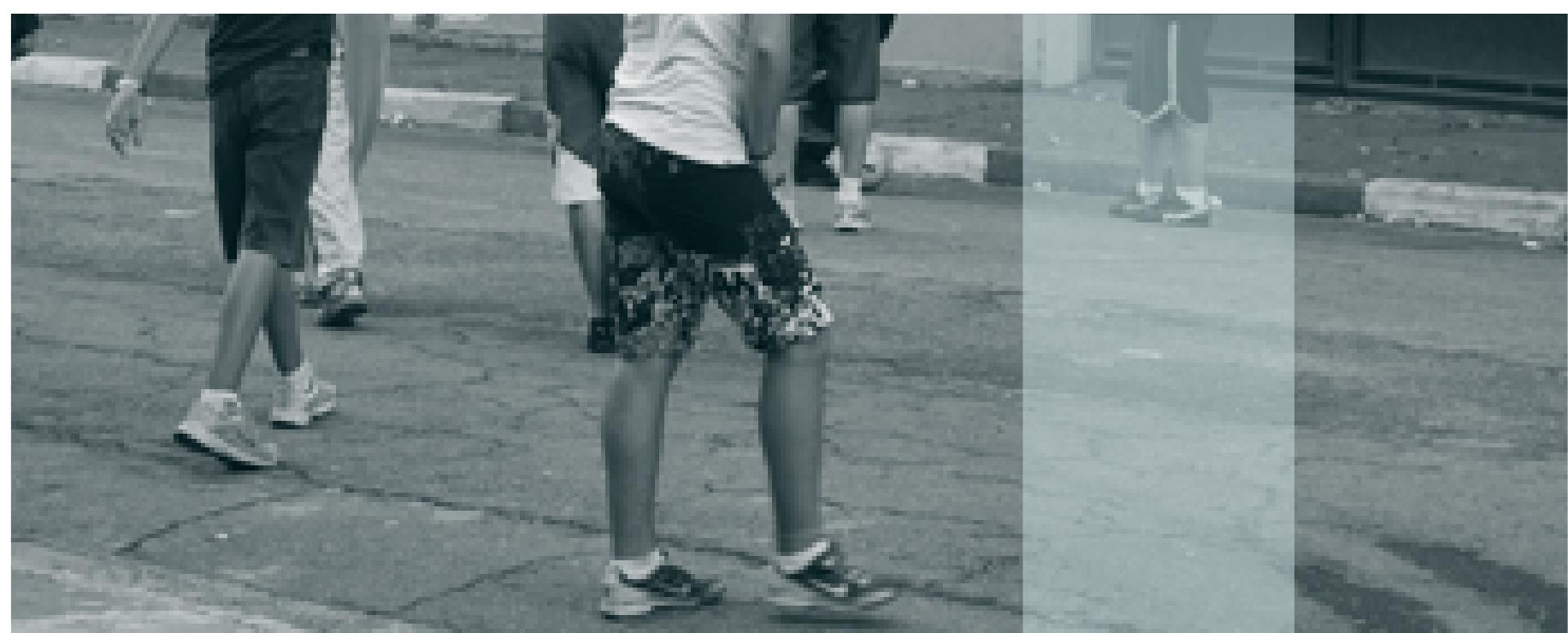


A reflexão sobre os diferentes significados da rua, sobre o impacto da violência na constituição do laço com a escola, convoca-o a se abrir ao entorno, discriminar as potências locais e desenvolver uma postura crítica e singular em relação à sua permeabilidade ao território.

A pertinência dessas questões para o campo da educação torna-se evidente nas palavras de Fátima:

Mas o que acontece na rua também é importante [...] hoje em dia aprende com tudo todos os dias, eu aprendo todo dia, a minha filha me ensina coisas assim, então é importante, você sempre aprende em todos lugares que você vai.

\section{De trás para frente, de dentro para fora e vice-versa.}

\section{Como vimos, o caleidoscópio que enlaça família e} escola produz combinações múltiplas a partir das trajetórias escolares de mães e filhos, da ressonância das práticas escolares na vida familiar e dos sons que emanam das ruas. Nos arranjos entre esses elementos, as expectativas dirigidas à escola atestam sua importância nesses territórios.

A escola é ponto de ancoragem do que é vivido na comunidade, ao mesmo tempo que abre portas diante da perspectiva de "um futuro melhor", reorganizando a relação entre passado e presente. Cada modo de interpretar a escola (com base nas experiências com ela ou nela) inaugura uma rede de significados que é capaz de alterar sobremaneira o modo como os alunos estão e aprendem na escola.

Ela tem saberes e modos de aprender que são particulares e valorizados pelas mães. 0 mundo lá fora tem outros, não menos importantes. Nesse contexto, as famílias convocam a escola a abrir passagem para que o samba possa se fazer ouvir lá dentro e reivindicam o cumprimento de sua função educativa - assim como os professores, como sabemos, pedem o mesmo das famílias.

Se professores e pais têm anseios semelhantes, há possibilidade de diálogo. As tensões características da relação família-escola nos territórios de alta vulnerabilidade revelam a potência do "lado de fora", exigindo a criação de novas respostas e modos de interagir. Aqui foram esboçadas algumas possibilidades.
Ora, quem mais pode abrir aos jovens as janelas do espaço e do tempo, quem lhes fará descobrir que um outro mundo é possível senão a escola?

Charlot, 2005, p. 137.

\section{REFERÊNCIAS}

CHARLOT, Bernard. Relação com o saber, formação de professores e globalização: questões para a educação hoje. Porto Alegre: Artmed, 2005.

. BAUTIER, Elisabeth; ROCHEX, Jean-Yves. École et savoir dans le banlieue... et ailleurs. Paris: Armand Colin, 1992.

. Da relação com o saber, elementos para uma teoria, Porto Alegre: Artes Médicas, 2000.

DIEB, Messias (Org.) Relações e saberes na escola: os sentidos do aprender e do ensinar. Belo Horizonte: Autêntica, 2008.

ROCHEX, Jean-Yves. Le sens de l'expérience scolaire. Paris: PUF, 1995.

ZAGO, Nadir. Processos de escolarização nos meios populares - As contradições da obrigatoriedade escolar. In: NOGUEIRA, Maria Alice; ROMANELLI, Geraldo; ZAGO, Nadir. Família e escola: trajetórias de escolarização em camadas médias e populares. 3. ed. Petrópolis: Vozes, 2007.

\section{NOTAS}

1 Pelo fato de serem aquelas que têm tempo e disponibilidade para participar tanto das ações do projeto quanto do cotidiano escolar dos filhos.

2 Os nomes foram trocados a fim de proteger sua identidade.

3 Fátima, Jandira e Edileusa têm três filhos, Marta tem quatro, Sônia tem cinco, Jucilene, Cláudia e Denise têm seis.

40 Índice de Desenvolvimento da Educação Básica (Ideb) foi criado pelo Inep em 2007 e representa a iniciativa pioneira de reunir num só indicador dois conceitos igualmente importantes para a qualidade da educação: fluxo escolar e médias de desempenho nas avaliações. Ele agrega, ao enfoque pedagógico dos resultados das avaliações em larga escala do Inep, a possibilidade de resultados sintéticos, facilmente assimiláveis, e que permitem traçar metas de qualidade educacional para os sistemas. 0 indicador é calculado com base nos dados sobre aprovação escolar, obtidos no Censo Escolar, e nas médias de desempenho nas avaliações do Inep, o Saeb - para as unidades da Federação e para o país - e a Prova Brasil - para os municípios. Disponível em: 〈http://portalideb.inep.gov.br/〉.

5 Segundo dados da Fundação Seade, o Jd. Helena está entre os 19 distritos que compõem o grupo de maior vulnerabilidade juvenil no município de São Paulo. Disponivel em: 〈http://www.seade.gov.br/produtos/ivj/〉. Acesso em: 2007.

6 Os dados são da Fundação Seade.

7 A síntese aqui apresentada a respeito de Douglas refere-se ao acompanhamento do jovem ao longo de quase dois anos no projeto Ação Família. Douglas procura com freqüência a equipe para falar de suas inquietações em relação à vida familiar e à sua participação em situações de violência. Neste texto, julgamos relevante complementar com essas informações a fala de sua mãe na entrevista quanto à impossibilidade de a filha brincar na rua. 